\title{
JUVENILE UNILATERAL TOTAL DEAFNESS OF UNKNOWN ETIOLOGY
}

By

JUNICHIRO NANDATE

Kokura municipal Hospital

Unilateral perceptive deafness in which one ear is impaired by $60 \mathrm{db}$ or more and the other ear essentialy normal is fairly uncommon.

The clinical pictures of seventy cases of such unilateral deafness have been studied.

Etiology : Many cases might have been attributed to ménièr's syndrome and sudden deafness (20 cases), local and general infection (10 cases), brain tumor ( 7 cases), head injure ( 4 cases) and streptmycine deafness ( 1 cases). The largest group (28 cases), however, was obscure the etiology and time of onset (Figure 1).

Age at onset or awarness of the impairment: most cases were under twenty years old, and far younger age group was most evident. (Figure 1,2).

Complication: Tinnitus and vertigo were observed in $29 \%$ and $24 \%$ respectively, but on the younger cases than twenty (Table 3, B) the complication were very seldom seen.
Through this observation, the group of unilateral impairment was differentiated because of the special picture presented from that of other unilateral deafness, and a term "Juvenile unilateral total deafness of unknown etiology was proposed by the author.

The characteristic of this group are as follows:

a. unilateral, total and permanent deafness in one ear, and normal hearing in other ear.

$b$. onset under twenty years old or in younger age.

c. principally, not complicated with tinnitus and vertigo.

d. no difference between male and female.

According to this study, the probable etiology could be infection, especially virus infection in very early life, but congenital origin should not be ruled out.

\section{片側高度神経難聴，殊に原因不明の若年性片側龍について}

小合市立病院耳寝咽知科

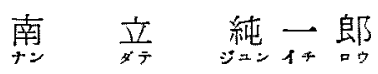

緒言

オージオグラムが多小の程度の非対称性を示すのは㥛 く普通である。しかし本椧文で检討寸る上うな片側整あ るいは片側性高度難聴，しか子それが感音系匴害に由来 するものは稀である，その中でも，聴神経腫瘍，化膿性: 迷路感染等の原因が片側性に作用する場合は別として， しかるべき明らかな原因もなく一側だけが算またはこれ に近く障害される機構は注目に值する.

所謂神経難㯖の診療においては，その原因や発生機㯕 から診ての悪グループへの鑑別彮断が必要となるが，こ
の過程において “原因不明の片側暨” は一つの重要な群 をなすものである。

著者は“若年期迄に発現する原因不明の片側整” の解 明のため，ひろく片側性の高度神経難聴を背景とした臨 床的観察を行い，2，3の與味ある知見を得たので報告す る次第である。

\section{研究方法並ひに所見}

\section{A）症例の選択}

凡之 1 力年間（昭和 34 年度）に我々の外来を訪权た 4,860 例の 患者（神経難聴 459 人を含む）の中か.51 側 
ほざ正常：他側高度神経難聴（全音域にわたつて60db 以上の損失) の70 例を研究刘象とした。

B）聴力像から文た分類

70 例を聴力障害の程度, 組み合わせ比より次の 4 型 飞分けた。

符！型）：良恥耳は全く正常（いずれの周波数でる聴 力損失 $10 \mathrm{db}$ に達しない). 他側は全婯または極めて僅 かの残㯖のあるもの (典型的片側蟹)。

第 II 型)：良聴耳俚全く正常，他側は聴力損失 $60 \mathrm{db}$ 以上に達するが麗ではない（典型的片側難㯖）。

第四型)：障管耳山第 I 型に類するが，良聴耳にる極 く軙、障害があるもの，即ち，1〜2の周波数で聴力損 失 $30 \mathrm{db}$ 程度 (準片側㰯).

第 N 型)：良㯖耳は第团型に，障害耳は第』型に類す るもの (集片側難聴)。

C) 所見

1）各型の構成人員と男女の分類を第 1 表に示してい る.

第 1 衰 片侧障害 70 例の型之男女別例数

\begin{tabular}{|c|c|c|c|c|}
\hline & \multicolumn{2}{|c|}{ 男女別 例数 } & \multirow{2}{*}{ 総例数 } \\
\hline & & 男 & 女 & \\
\hline I & 型（典型的片側熹） & 15 & 17 & 32 \\
\hline $\mathbb{1}$ & 型 (典型的片侧難聴) & 10 & 9 & 19 \\
\hline [I] & 型（淮片侧毁） & 8 & 3 & 11 \\
\hline N & 型（準片側難聴） & 4 & 4 & 8 \\
\hline & 竍 & 37 & 33 & 70 \\
\hline
\end{tabular}

第 I 型（典型的片側警）が凡そ半数を占めている.本 研究の立場からみれば，第出型は本質的には第 I 型に属 寸るので，これを加えると（典型的）片側蟹は更に多く なる。

男女間に有意の差はみられない。

2）片側障害 70 例を含めて神経難聴 459 例の難㯖原因 別分類と片側障害型との関係を第 2 表に示している.

原因不明群 112 例は患者が難聴発生の時期，原因のい ずれる記憶していない症例群である。

ストマイ難聴 31 例中の第 [ 型 (舆型的片側蟹) の 1 例はストマイ髄腔内注入例である。

ムンプス 5 例中の 1 例では，耳下腺腫脹側と反対側耳 に塑を発生している。

老人性難聴、ストマイ難聴及び職業性難聴では原則と
第 2 表 神経難聴 459 例の原因別分類と片側障害 の型及びその例数

\begin{tabular}{|c|c|c|c|c|c|c|}
\hline \multirow{2}{*}{ 聴 原 因 } & \multirow{2}{*}{ 総例数 } & \multicolumn{4}{|c|}{ 片側障害の諸型 } & \multirow{2}{*}{ 計 } \\
\hline & & I & $\llbracket$ & II & IN & \\
\hline 老人性難聴 & 38 & 0 & 0 & 0 & 0 & 0 \\
\hline 音 響 外傷 & 53 & 0 & 0 & 0 & 0 & 0 \\
\hline ストマイ難㗜 & 31 & 1 & 0 & 0 & 0 & 1 \\
\hline 頭部外傷 & 29 & 1 & $1:$ & 2 & 0 & 4 \\
\hline 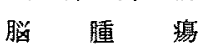 & 13 & 3 & 1 & 3 & 0 & 7 \\
\hline 局 所 感 染 & 12 & 2 & 1 & 0 & 0 & 3 \\
\hline 全 身 感 染 & 10 & 2 & 01 & 1 & 0 & 3 \\
\hline ムンプス & 5 & 4 & 0 & 0 & 0 & 4 \\
\hline メ病症䐅群 & 104 & 1 & 4 & 0 & 3 & 8 \\
\hline 突 発 難 聴 & 124 & 6 & 3 & 1 & 2 & 12 \\
\hline 原因不明群 & 122 & 15 & 9 & 2 & 2 & 28 \\
\hline そ & 7 & 0 & 0 & 0 & 0 & 0 \\
\hline 計 & 459 & 35 & 19 & 9 & 7 & 70 \\
\hline
\end{tabular}

第 1 図各種原因による片側障害 70 例の年令别 分布

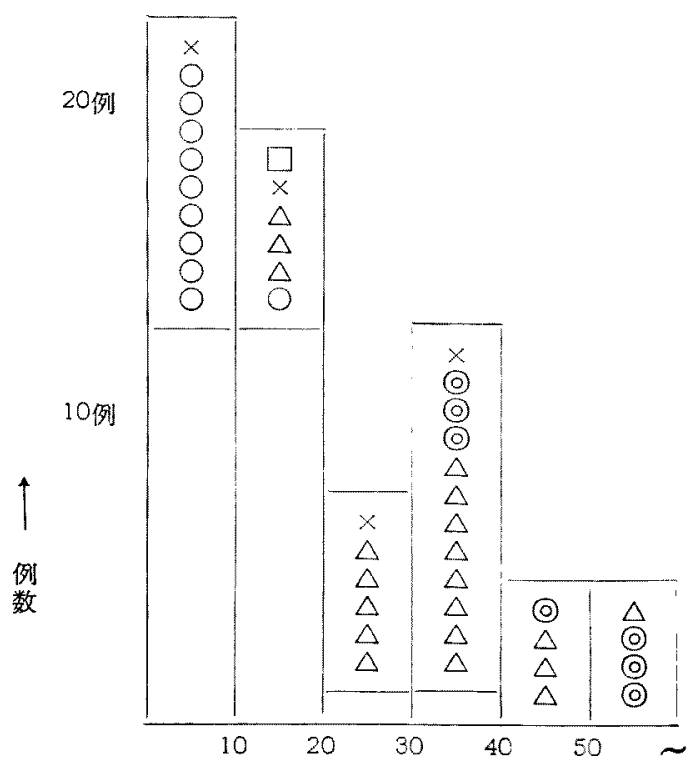

年令 $\longrightarrow$

○は感染， $\triangle$ はメニエール症候群（笑発難聴を含

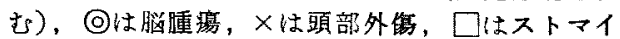
中毒が原因と推定されたもの，空白攔は原因不明 のもの. 
して片側障害の形をとらない，頭部外傷，急性音響外傷 は稀に片側整をきたし，畄腫㻛，又病症候群，感染は かなり頻回に片側障害を発生する。

原因不明群については後で一括検討する。

3）片側障害 70 例の年令別ヒストグラムを作り，原因 の推定できるるのを，それぞれの印で区別すると，20才 未满に和ける空白柱の存在は特異的である(第 1 図). これが第 2 表の原因不明群の片側障害 28 人中の 25 人を 占めている。

4) 片側障害 70 例を 20 于以上の A 群と, 以下の B 群，更に B 群を原因または発病の状況を記憶または確 認できるもの $\mathrm{B}_{1}$ 群とできない、 $\mathrm{B}_{2}$ 群に分けて，耳鳴， 眩量合併の有整を調べると第了表を得る。

第 3 表 片側障害 70 例の年令による分類と合併障害

\begin{tabular}{|c|c|c|c|c|c|}
\hline & & & 鳴 & 眩 & 祭 \\
\hline & & b & क L & あり & な $\iota$ \\
\hline A & $=3$ & $\begin{array}{r}24 \text { 例 } \\
(86 \%)\end{array}$ & $\begin{array}{r}49 \\
(14 \%)\end{array}$ & $\begin{array}{r}20 \text { 例 } \\
(71 \%)\end{array}$ & $\begin{array}{r}8 \text { 列 } \\
(2900)\end{array}$ \\
\hline $\mathrm{B}_{1}$ & $\vdots \vdots$ & $\begin{array}{r}4 \\
(27)\end{array}$ & $(11)$ & $\left(13^{2}\right)$ & $\begin{array}{c}13 \\
(87 \%)\end{array}$ \\
\hline $\mathrm{B}_{2}$ & 27 & $\left(\begin{array}{l}1 \\
4\end{array}\right)$ & $(96)$ & $\left(7^{2}\right)$ & $(93)$ \\
\hline 暗 & 20 & $\begin{array}{r}29 \text { 例 } \\
(41 \%)\end{array}$ & $\begin{array}{r}41 \text { 例 } \\
(59 \%)\end{array}$ & $\begin{array}{r}24 \text { 例 } \\
(34 \%)\end{array}$ & $\begin{array}{r}46 \text { 例 } \\
(66 \%)\end{array}$ \\
\hline
\end{tabular}

A は20才以上. $B_{1}$ は20才以下, 無病の状況を 割合詳しく記愤しているもの. B 壮20才以下. 発病の時期の極めて淡然としているもの。

耳鳴, 眩最合併率は $\mathrm{A}$ 群に䩙べて $\mathrm{B}$ 群, 殊に $\mathrm{B}_{2}$ 群 は著しく小さい。

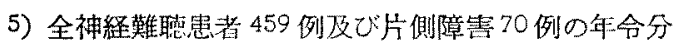
右を第 2 図に示している。

片側障害は若年期で怡相刘的に藷しく多い，

以上の所見を棇括すると，

1) 片側高度障害の凡そ半数性 20 于末満，殊に 13,14 才迄澄生している。

2）若年期 (20才未満) 飞発生した片側高度障害の大

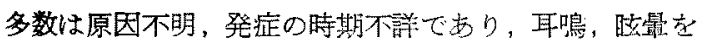
伴わない.

3）その発生頻度，症状について，男女差は認められ ない.

4) 各種神释難聴中に片側障害の占める割合は若年期 では著しく大きい。
第 2 図破線性程難㯖 459 例の应例数

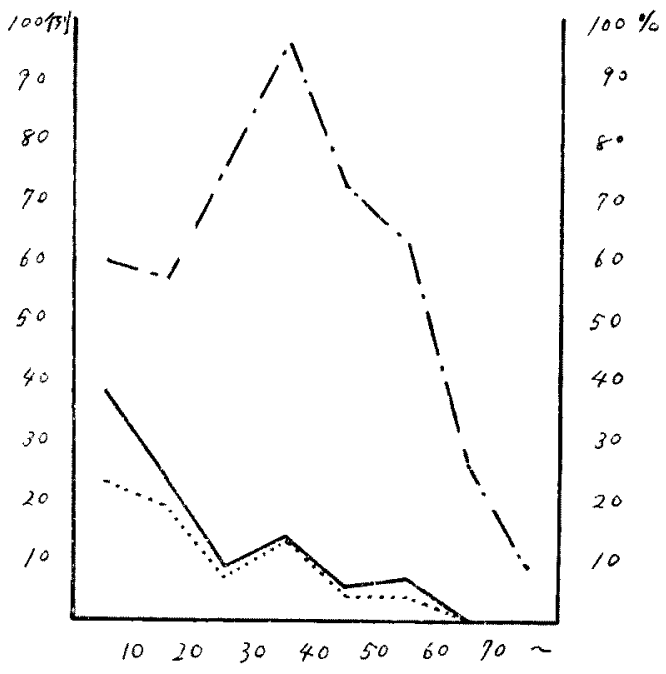

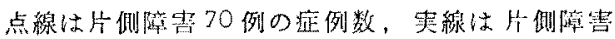
の全神経難聴に刘子る西分率。

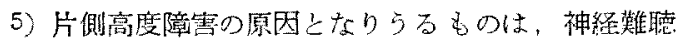
原因群の中のある限られたものだけである。

\section{考按}

著者は先汇発表した論文 29) にお゙いて「オージオグラ 么の左右対称像」を説明する基本的態展としては「原因 の左右平等性」を当てるべきだと說いた。この論攵で対 象としているのは「著しい非効称」をるつ症例群であ る.

神程難聴原因は原則的には，左右耳に同時に㗢らく （平等といら意味ではない）。従つて 1 側正常，他側高度 難聴をきたす機構は特異的のものである．夹際の德力検 查上の経験でも「両耳阙に50db 以上も差のある片側高 度神経難聴」はそう管々経駼するものではない。

統計学的な現象として，稀な事象，特異な测定值飞数 多い試行中には钼察されるものである。しかし，特異な 非対称オージオグラム必数多い症例中に性発するとし てこれを見逃すわけにはいかない，知畏り，てこには特 殊的な事情を調查して，因果律的なるのを求める努力を せ杖ばならない。

A)；発生頻度の概観

全対象70 例は 4680 人の外来患者, 459 例の 神絰難聴

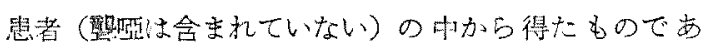
る.

又一方，数千人に及占騷音下学働者及び学生，㝠意の 
選別检査中に打ける著者の経験 ${ }^{193}$ から推しても，片側 高度障碍者は非常に稀ではあるが一般健康者の中にも数 百人中に 1 人位の割合で存在するようである。

最近, Everberg (デンマーク ${ }^{2)}$ は 183,000 人の学童

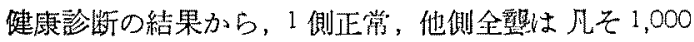
人に 1 人の割合で発見されたと報告している。

B)：原因の種類と発生頉度

i）原則的には片側陌碍を生しないもの

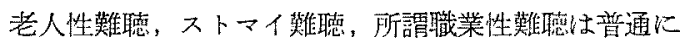
は詨称性オージオグラムをとる疾患であり ${ }^{2.91}$ ，片側高 度障碍と乙て発症すること恃ずない，たた「ストマイ 難聴」についてはその䯣腔内注入例て極く稀に片側高度

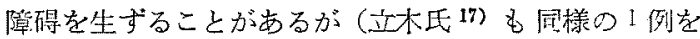
報告している)。これは「ストマイ」骵腔内注入が筇注 括けるよりも作用激烈であるだけでなく，かっる症例 では脳膜炎を例発している例が多いからであるう。

ii）稀比は片側障碍を生ずるもの

頭部外傷，急性音篦外傷（強大音響，爆発）の場合に はその大多数は非対称性オージオグラムを生ずる23)，

しかし本論文に㧍けるよらな片側だけの高度障碍索生ず ることは割合に少ない，頭部外傷，急性音響外賃のよう な原因は同一個人には瀕回には働らかない，穴の原因心 クトルを種々樣々の方向に向から，従つて難聴の非対称 像もささざをとなる。いろいろの程度の非詨称性㜔碍の 中に法倒のみの高度障碍もありらるわけである。

iii）頻回に片側障碍老伴う子の

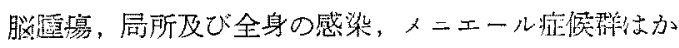

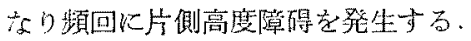

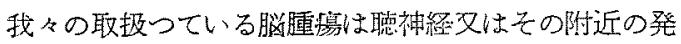
生例が多いので当然の所見である。

普通の急性又は慢性の中耳炎，外耳炎は感音性弫㯖を きたすことは稀である。しかし流行性耳下腺炎、耳部帯 状匋行疹の上らに耳又はその附近の感染が高度の感音性 難聴を生ずる場合がある。

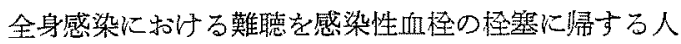
もある上らに，片側障碍の発現は別に不思議ではない。

マニェール氏病にお汁る内耳失調か摩々片側性に現わ れるのはよく知ら机ている.しかし典型的メニ×ール氏 病では高度の片側難聴をきたすのは制合に少ないとみ られる。突発難聴は非常に磨々片㑬高度障碍を伴う。こ の原因については未だ決定的なものはないが，所謂突発 難聴之されているもの今大多数は広義入症々密接な関係 が想像されている21).
原因不明，発症不詳群の中にも片則高度障碍は少なく ない。これについては後て詳述する。

以上は第 2 表の所見について，著者の解釉法を述べた ものである.W. Hughson) は種々の程度の unilateral deafness 1,400 例を観察してその原因として局所感染, toxic involvement, 外傷, メニエール氏病, 腫埸をあ け゚ている，彼の観察例は著者の片側高度障碍と同一では ないが，泀ら゙同一䫀向の所見とみるべきであうう。

C)：合倍症候

オージオグラム所見に拠つて一括したこの疾患群は， 種々の原因, 種々の疾患から成りたつている。しかし， これを耳鳴，眆最合併の存否について調べる時，この矮 患群が二つの群瑓然と分たれるのは一敬汇值する．即

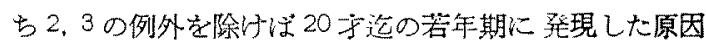
不明の片側障碍群では耳鳴，矓暈を伴和ず，これに対し て20于以降に発生した原因及は発拝の明らかな片側難 聴群では殆んぞ常に耳鳴を，そしてかなり雾々䏠最を伴 つている.

雪群の耳鳴及び䏠最合併の差異が難聴原因，難聴発生 ふカニズムの本質的違い上よるのか，又心年令に伴う身 体的，心理的要因に上るのか忧即断学許さない、著者は 以前の諭文 ${ }^{20)}$ に拈いて，神経難聴全般を一括して考学 れば，耳鳴は20才以下群は20才以上群に比して統計的 に有意に，著しく少ないことを示したことぶする。

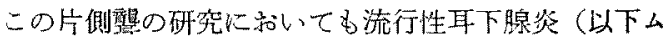
ンプスと略記す）その他の局所的感染による群では耳 鳴，睮聂は著しく少ないが，同時にこの群を構成する患 者の年令分布も14，15 才以下の若年者が生倒的に多い， これに対して，大島等 ${ }^{18)}$ 及び中田氏 ${ }^{16)}$ 報告例のムン プス憼ではかなり高率に耳鳴，睹最を訴えているが、こ こては比較的高令者が多い上うである. G. Everberg ${ }^{(4)}$

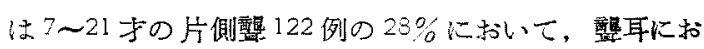
ける前庭機能の欠如を镜察しているが，耳鳴，眩量につ いては統計的数值を記载していない，記载の模㥞から推 察して，耳鳴，瞇最は非常に少なかつた之想像される。

D)：年令及び男女別分布

著者の観察例では男女差は証明されない，立木氏も同

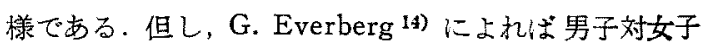
は76 詨 46 で，統計的有意に前者に多かつたと述べてい る.

年令分布は第1図のように，20才迄に最毛多く，以 後年令と共に少なくなる。

年令と共に，他のいろいろの原因のために㯖力は低下 
するので，若年期の片側難㯖と同じ原因，機構が作用し ても既に存在していた他側障䉕のために片側障㕩として 取り报われない場合（例えば，上述第 I型が第正型之み られる）すあるが30—40-台の分布をみる時，やはり 本貿的に20チ台迄に最も多く発生すると解积すべきで あろら。

原因不明の若年性片側㞟について

上述の上5に，片側障亚の臨床像を数ヶの方向から観 察し，その成因解明に努力してきたが，何か大きい空傹 を感ぜざるを得なかつた。それは原因及び発症の時期不 詳の群が 70 人中 28 人の多き占めるからである。

年命分布を双る時，この28人中の 25 人は20才末満，

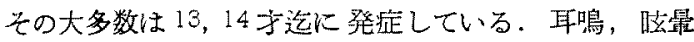
の合羦も他の群しは一線を画しているよ5に見える，即 ち神経難㯖の中には「若年期沦に発生するが，その原因 及び発生時期不詳の耳鳴，距羁を伴わない片側高度難 聴」各存在する。

最近. 非常に広搉な研究を発表した Everberg 9)10)11 12) 11) $の$ unilateral total deafnese, 代木氏 22) $の$ 若 年者に見られる喓性進行性偏側性内耳性難聴」もこれに 談当すると著者は推定している。

A) 臨 床 像

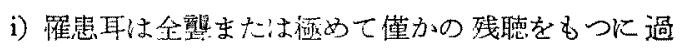
ぎない，他側耳は全く正常、例党軽度の隌害があつて も，それは他の原因によるものである。

ii) 20 才末満の若年期，大多数は更にす゚つと奻、頃 (先天性の可能性む含わて) 迄に霍患している.

iii）男女間に本質的の善異はない。

iv)大多数は耳鳴，矓最を伴わない。

v)局所的化膿雷，外稘あるいは腄瘦等の明眭な原因の 㤎められるものは定的に除外已饥る。

vi）片側高度神経難聴を原因別に分類する時，本群保 最む大きい比重をむち，全片側高度障害例の $1 / 3 \sim 1 / 2$ を占める。

Everberg ${ }^{15)}$ によれば，若年者の片側琶 122 例の中 $82 \%$ は先天性であり，徭天性2! 例中の3 例のみが8才 以降に生じ，他は繶てそ和以前に発見されている，更に

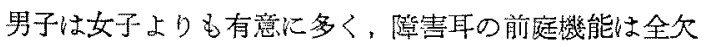
$28 \%$, 保存 $72 \%$ 乙婄羢している.

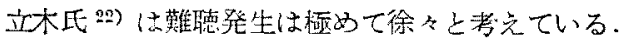

B) 原 因 詥

因果関係のはつきりした原因のする症例は定義的に除 外されているので発生の不明膫な，しか子若年期迄に発
生している片側繁の原因を求めるわけである。

このような原因を求めるにしても，次の上5な既に种 経難聴の原因，殊に片例障書つ原因として認められてい るもの>中から探すべきであるう．即ち，

i) 感染. 局所的あるい柱全身的感染, 細菌感染市る いはビールス感染。

ii）先天性または遗伝性発生，あるいはその受傷性の 負荷.

iii）頭部外傷，分婏時の障害.

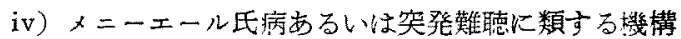

v) 膯堙堭.

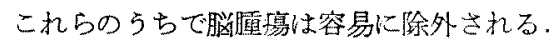

幼少期に拈ける頭部外稘はかなり多いか曲知れない。 しかし，本疾患を説明する程の頍部外賃性片側㻎がある と仮定するには，それに数倍，数十倍する種々の非对称 性の頭部外稘性難聴の存在を必要とする。著者は大の上

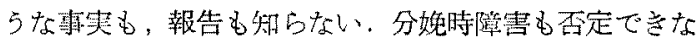
いが，本研究の70例中には著しい雚産例は皆無である。

Everberg ${ }^{11)}$ む分婏应害には否定的である。

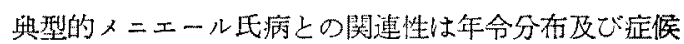

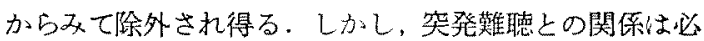
らす゚し乎否定できない。

先天性発生あるい:邅伀的要因について

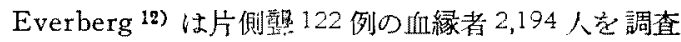

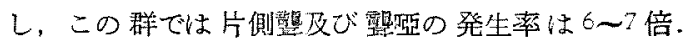
endogenous partial neurolabyrinthpathy (内因性神経

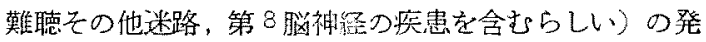
生率は11倍も正常者群上り多かつた。そして彼の122 例の中の25〜30\%は遗伝によるものと者え，更にSmith 9) の家系も参考に入れて，片側冀は irregular dominance に嘥つて遗伝する上推察した。しかし遗伝するのは

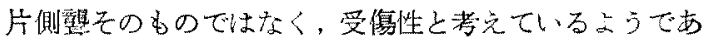
Ђ.

A. Marschak 2) の稓察した片側壁50 例の中には先天 性と考光られるbの7例方古つたが，先の中には Ham-

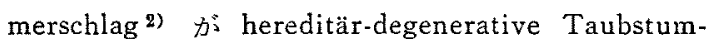
maeit に合併し易い異常として挙げた乱視，両眼不同視

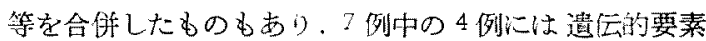
が濃いとしている。

立木氏 22)はこの疾患の臨床像からみて，遺伝要素を 重視している。

遗伝的聴力障害における対称像を強調したB. Langen- 
beck ${ }^{3}$ ) 自身 \& 300 例の観察結果，その:10\%に非対称性 オーシオグラムの存在を諗めた，彼は聴力障害の遗伝様 式を論じた中で，モザイク型遗伝即ら例えば右耳に父親 の、左耳に母親の聴力像の遗伝した例を举げている. 若 しモザイク型遗伝が存在するとすれば遗伝性片側裂の出 現を理解し易くなる。

小耳症や羿視症が両側性よりも，むしろ片側性に現わ れるよらに，鳟または難聴あるいはその素因が，稀に先 天性に片側性に負渮されても不思福ではない。

たざ，本疾患の大多数が (1) 幼少時迄敒生し，(2)而 側障害であるため，てれが先天性に存在したのか，生後 に発生したのか判定は非常に困難である。

片側䆏の原因としての感染について

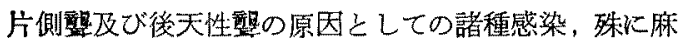
疹や筃膜炎は古くからその可能性を信じられている，そ の根抛として次の点があげられる

1) 麻达，ムンプス，ヘルペス及び膎膜炎に直ぐ引き 続いて，高度神経難聴の発生した症例の観察例は非常に 多い。

2）麻掺，ムンプス，へルペスその他の感染は若年期 に王倒的に多い、これは若年期片側障㫪の年令分布と平 行関係にある。

3）この諭文における片側障害 70 例の中，感染性とみ られる10例（第2表）の耳鳴，鈿最合作の模様は原因 不明の若年期片側臀に似ている。

4) 感染は片側性を説明し易い。

C. E. Kinney ${ }^{5)}$ の若年者（17〜25才）の難聴 2,628 例の分析によれば，感音難聐 940 例中の 310 例は no hearing one ear, normal hearing other ear (著者の 典型的片側鳘) である。その原因は 131 例 (42.3\%) は 不明, 74 例 (23.9\%) は probable menigitis, 72 例 (23.2\%) は possible measle, 33 例 $(10.6 \%)$ は posible mumps となつている. R. B. Scott ${ }^{6)}$ 及び J. R. Lindsay and W. G. Hemmenway ${ }^{8)}$ の調查以よれば，米

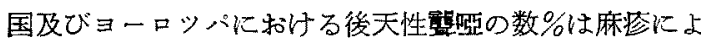
るとされている。

しかし，若年期における聴力障害殊に片側意の碓認は 困難であり．伝染性疾患との関連も確寒に証明された訳 ではない，彷つて，ある種の伝染性疾患と聴力障害との 因果関係に否定的な意見も少なくない。

Eagles 6)はムンブス患者 1,664例. Mcquinnes and

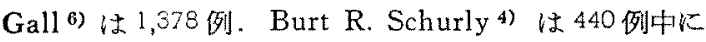
難聴合伯を 1 例も認めなかつたとしている。
しかし，ムンプス治療経過中の片側重発生の模様を詳 細に記載した A. J. Coombs ${ }^{6}$, Lindsay and Zuidema Б）その他の記録. ムンプス及び猩妅熱についての Everberg 10) 11) の同様の記載. 7 カ月男子に拈ける麻疹によ る内リンパ迷路尖の剖検例 ${ }^{8)}$ 等々，麻疮，ムンプス， 猩紅熱等が片側傿の原因または誘因となりらることはま 違いないよらである。

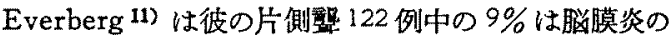
病歴がありこれは正常者のそれより180倍も多い頻度 である，即ら，脳膜炎を有力な原因と考えた。

感染泟殊にビールス感染のらちには不㩆感染 (subclinical infection) のあることはよく知られている。しか もこの不影感染が若年者の片側算あるいは突発難聴の原 因となりらることる注目されている，母親のムンプス経 過中にその子を酮つた突発難聴の 1 例 (J.R. Lindsay) 耳下腺蕾脹と反対側に蟹の生じた諸例 (Everberg ${ }^{10)}, \mathrm{M}$. Tayler 4)，W. Hughson 4) 及び著者)はその-つの根 拠となる。

Van Dishoek はムンプン感染の存否の検査に補体結 合反応はじめて応用したとされているが，この方法に より O'Neill 13) るムンプス不顕感染によると思われる 片側高度神経難聴 5 例を記载した。同様に Enders 4 ) (16 例の原因不明神絽難㬝者にムンプス補体結合反応及 び皮内反応陽性 6 例) 及び大島，降矢（3例のムンプス 難㯖者に高い抗体価）等の報告るある。

以上，本疾患または疾患群の原因として，

i) 感染殊にビールス感染

ii）遗伝性または非遗伝性の先天性発生

iii）先天性片側㤬素因負荷に感染または中㲨作用の重 椱

の3つの場合が最も有力と考えられる、しかし，1） 発生頻度が非常に稀，口）奻少見の片側障害の確認は困 難，一）血縁者の調查も膨大な人数を対象とせねばなら ない等々の理由のため，原因の早急な礁諗は困嚾であ る、各方面からの注意深い倠察例の集積により，はじめ て解決されるるべ問題である。

\section{総括並びに結論}

対称性オージオグラムが偶然には生じないように，片 側高度神経難聴もまた洪して偶然には発生しない，大数 例を統計的にみる時，難聴原因とオージオグラム対称像 との間はかなり濃い相関閣係がある。

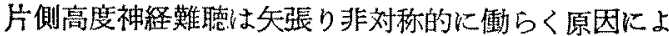
り発生する。即ち脳朠滰，局所及び全身の感染，х二エ 


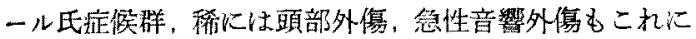

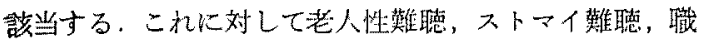
業難聡は㚙通には斯かる原因とはなり得ない，遗伝に起 因する難德ではその大多数は正確な対称像をとるか゚，稀 には片側高度難㯖も発生するか子知れない

片側高度神絽難聴群中の大きい比重を占めるものに著 者のいら「原因不明の若年性片側籃」がある。この群は 発生年令，合併症に拈いて他の群上一線を割するよらに みえる. その原因として最も理解し易いものは小照期に おける感染，殊にビールスの不顕感染である。しかし，

遗伝性または非遗伝性の先天性発生あるい娆天性鱼㑤 の可能性も否定できない。

以上は片側性高度神経難聴 70 例を中心とする459 例 の神経難聴患者の観察より得た推論である。

\section{文献}

1) Spira, $R$ : Über Heredität bei Ohrenkrankheiten. Mschr. Ohrenheilk. 48, 354, 1914.

Marschak, A.: Über 50 Fälle von Einseitige Taubheit, davon 7 Angeboren. Ztsch. f. L.R.O. 21, 145, 1931. 3) Langenbeck, B.: Das Symmetriegesetz der Erblichen Ztsch. Hals-usw. Heilk. 39, 223, 1936. 4) Hughson, W.: Unilateral Deafness. Arch. of Otolaryng. 41, 379, 1945. 5) Lindsay, J. R. and Zuidema, J.J.: Inner Ear Deafness of Sudden Onset. Laryngoscope. 60, 238, 1950.

6) Coombs, $A$.

$J .:$ Deafness Following Mumps. Laryngoscope. 62, 205, 1952. 7) Kinney, C. E.: Hearing Impairments in Children. Laryngoscope. 63, 220, 1953.

8) Lindsay, J. R. and Hemenway. W. G.: Inner Ear Pathology Due to Measles. Ann. of Otol. 63, 754, 1954. 9) Everberg, G.: Hereditary Unilateral Deafness. Acta oto-laryng. 45, 303, 1957. 10) Everberg, G.: Deafness Following Mumps. Acta oto-laryng. 48, 397, 1957. 11) Everberg, G.: Eti- ology of Unilateral Total Deafness Studied in a Series of Children and Young Adults. Ann. of Otol. 69, 711, 1960. 12) Everberg, G.: Further Studies on Hereditary Unilateral Deafness, Acta oto-laryng. 51, 615, 1960. 13) O'Neill, J.J.: Sudden Unilateral Hearing Loss Attributable to $\mathbf{M u}$ mps. Journal of Speech and Hearing Disorders. 25, 55, $1960 . \quad 14)$ Everberg, G.: Unilateral Total Deafness in Children Clinical Problems with a Special View to Vestibular Function. Acta oto-laryng. 52, 253, 1961. 15) Everberg, G.: Investigation into Unilateral Deafness und Absence of Vestibular Function With a Particular View to the X-Ray Appearence in the Inner Ear. Acta oto-laryng. 52, 47, 1961. 16) 中田一郎：流行性耳下腺筷性恩器障

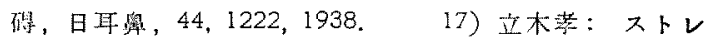
プトマイシンに因る惁器障得に就て, 日牙率, 58, 1228, 1955. 18) 大身弘至, 外：流行性耳下腺炎性熟の臨

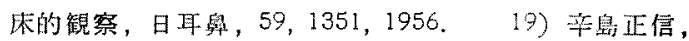
南立純一郎：撰別聴力检査法の研㠾，耳異，6: 174,

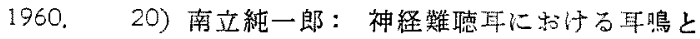

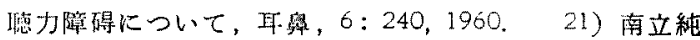
一郎，武田秀隆：笑発難㯖。耳舅，7：1，1960，22) 立木孝：若年者に見られる慢性進行性霹側性内耳性難 畮について，日耳粤，65：401，1962。23）南立純一 郎：神経擎聴の原因とオージオグラム対称性，日耳粤， 65,10 号, 1962.

恩師河田政一教授の御指導を感謝します 本 墖文の要旨は第 7 回オージオロジー学会で口演 した。

（原穞到着 $=$ 昭和 37.8 .2 日） 